\title{
PENGARUH LINGKUNGAN KERJA KELOMPOK TANI DAN PERANAN SUMBERDAYA KONTAK TANI TERHADAP KINERJA PETANI DESA SIDO URIP KABUPATEN BENGKULU UTARA
}

\author{
Agusri Ramadhan ${ }^{1)}$, Satria Putra Utama ${ }^{2)}, \operatorname{Irnad}^{2)}$ \\ 1) Dinas Tanaman Pangan Hortikultura dan Perkebunan Provinsi Bengkulu \\ 2) Jurusan Agribisnis Fakultas Pertanian UNIB
}

\begin{abstract}
ABSTRAK
Peran kontak tani dalam meningkatkan kinerja anggota kelompok tani pasti sangat dirasakan manfaatnya. Peran kontak tani yang memberikan kemajuan usaha tani para tani tentunya juga dipengaruhi oleh faktor-faktor yang ada seperti lingkungan kelompok tani. Tujuan dari penelitian ini adalah menganalisis pengaruh peranan sumberdaya kontak tani terhadap kinerja petani, pengaruh faktor lingkungan kerja kelompok tani terhadap peranan sumberdaya kontak tani dan menganalisis pengaruh faktor lingkungan kerja kelompok tani terhadap kinerja petani. Responden penelitian adalah anggota kelompok tani yang tergabung dalam petani pemakai air yang terletak di Desa Sido Urip Kabupaten Bengkulu Utara. Metode analisis data yang digunakan adalah analisis SEM dengan menggunakan aplikasi WarpPLS yang digunakan untuk melihat hubungan kausal antar variabel yang diteliti. Hasil penelitian diperoleh hasil bahwa lingkungan kelompok tani berpengaruh terhadap Peran sumberdaya kontak tani dengan $p$-value $\leq 0,01$ dengan (tingkat keyakinan 95\%) dan nilai estimasi 0,46. Kemudian Variabel Peran sumber daya kontak tani juga berpengaruh signifikan terhadap Kinerja petani dengan $p$-value $\leq 0,01$ dan nilai estimasi 0,41 . Terakhir, variabel lingkungan kelompok tani berpengaruh signifikan terhadap kinerja petani dengan $p$-value 0,04 dan nilai estimasi sebesar 0,15 . Oleh karena itu dapat disimpulkan bahwa semakin baik lingkungan kerja kelompok tani maka dan semakin baik peran sumber daya kontak tani maka kinerja petanipun akan semakin baik.
\end{abstract}

Kata Kunci: Lingkungan Kerja, Kinerja Petani, Kelompok Tani, Kontak Tani

\section{PENDAHULUAN}

Kebijakan yang diambil dalam upaya mempercepat proses pembangunan di bidang pertanian antara lain adalah meningkatkan kemampuan petani dan kelembagaan kelompok tani agar mampu secara efektif menampung dan melaksanakan kepentingan kegiatan petani.

Penumbuhkembangan Kelompok Tani (Poktan) dan Gabungan Kelompok Tani (Gapoktan) di Wilayah binaan (WILBIN) Penyuluh Pertanian atau Wilayah Kerja Penyuluh Pertanian (WKPP), perikanan dan kehutanan merupakan faktor utama agar kepentingan petani dapat lebih diakomodasikan dalam kebijakan pembangunan.

Kelompok tani merupakan suatu wadah tenpat para petani dan keluarganya secara non formal belajar dan berkomunikasi untuk saling tukar informasi dalam memecahkan masalahnya atas dasar keserasian dan keselarasan. Kelompok tani di pimpin oleh seorang ketua sekaligus menjadi kontak tani yang dipilih oleh anggotanya dalam suatu wilayah domisili atupun hamparan wilayah guna memanfaatkan sumberdaya pertanian secara berkelanjutan dengan tidak mengabaikan kearifan lokal yang telah 
ada. Kontak tani merupakan perpanjangan tangan penyuluh pertanian dalam pembinaan dan pengembangann gabungan kelompok tani. Dilihat dari segi transformasi inovasi pertanian, pemanfatan khalayak sasaran strategis seperti kelompok tani merupakan kunci akhir dalam penentuan keberhasilan program pembangunan pertanian. Rendahnya peran serta sumberdaya kontak tani dalam upaya mencapai tujuan kelompok tani merupakan salah satu permasalahan dalam penyuluhan pertanian karena berbagai indikator peranan sumberdaya kontak tani belum menunjukkan peningkatan tujuan kelompok tani sesuai dengan harpan meskipun telah dilakukan berbagai upaya melalui pelatihan, kursus tani, magang, rembug kontak tani dan lain sebagainya. Oleh karena itu rumusan masalah dalam penelitian ini adalah:

1. Bagaimanakah pengaruh faktor lingkungan kerja kelompok tani terhadap peranan sumberdaya kontak tani?

2. Bagaimanakah pengaruh faktor lingkungan kerja kelompok tani terhadap kinerja petani?

3. Bagaimanakah pengaruh peranan sumberdaya kontak tani terhadap kinerja petani?

Hasil dari penelitian ini diharapkan dapat memberikan informasi dan penegasan (comfirmatory) tentang peranan sumberdaya kontak tani dalam meningkatkan kegiatan kelompok tani dan gabungan kelompok tani.

\section{METODE PENELITIAN}

\section{Waktu dan Tempat Penelitian}

Penelitian ini dilakukan pada bulan Februari 2018-Juni 2018 terhadap seluruh anggota kelompok tani Tanaman Pangan/padi sawah di Desa Sidourip, Kecamatan Argamakmur, Kabupaten Bengkulu Utara.

\section{Populasi dan Sampel Penelitian}

Populasi dan Sampel dalam penelitian ini adalah seluruh anggota kelompok tani tanaman pangan atau petani padi di desa Sidourip, Kecamatan Argamakmur, Kabupaten Bengkulu Utara sebanyak 131 orang.

\section{Variabel Penelitian}

Penelitian ini terdiri dari 3 (tiga) variabel, yaitu 1 (satu) variabel bebas (lingkungan kerja kelompok), 1 (satu) variabel bebas antara (peranan sumberdaya kontak tani), dan variabel terikat yaitu kinerja tani.

Adapun indikator masing-masing variabel adalah sebagai beikut :

1. Lingkungan kerja kelompok tani, terdiri atas (a) Hubungan kontak tani dengan anggota kelompok tani, (b) Pengolahan Lahan Pertanian, (c) Sistem Pola Tanam, (d) Perawatan dan Pemupukan Lahan dengan Pestisida, (e) Pengelolaan Jaringan Irigasi, (f) Perawatan Jaringan Irigasi, (g) Penggunaan Alat Mesin Pertanian, dan (h) Sistem Penghematan Air.

2. Peranan sumberdaya kontak tani, terdiri atas : (a) Memfasilitasi anggota kelompok tani dalam mencapai tujuan kelompok tani, (b) Membantu para anggota memenuhi kebutuhan, (c) Mewujudkan nilai kelompok, dan (d) Mewakili pendapat anggota kelompok tani dalam berinteraksi dengan pihak lain.

3. Kinerja petani, terdiri atas : (a) Tingkat pendapatan anggota kelompok tani, (b) Proaktif dan kepatuhan anggota kelompok tani, dan (c) Kepuasan anggota kelompok tani.

\section{Analissi Data}

Metode analsis data yang digunakan adalah metode analisis SEM (Structural Equation Modeling) yang digunakan untuk melihat hubungan kausalitas antar variabel yang diteliti. 


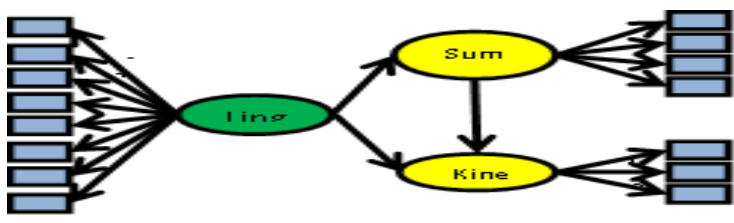

Gambar 1. Diagram Alur SEM

Keterangan:

$\lambda$ : Hubungan Variabel manifest terhadap variabel laten

$\gamma$ : Hubungan variabel laten eksogen terhadap variabel endogen

$\beta$ : Hubungan Antar Variabel endogen

\section{Evaluasi Kecocokan Model}

a. Menilai Measurement Model(Outer Model)

\section{1) Discriminant Validity}

Nilai loading pada konstruk yang dituju harus lebih besar dibandingkan dengan nilai loading dengan konstruk yang lain (Husein, 2015).

2) Convergent Validity

Ukuran reflektif individual dikatakan berkorelasi jika $\geq 0.5$ dengan konstrak yang ingin diukur.

\section{3) Composite Reliability}

CR dikatakan baik bila memeiliki nilai $\geq 0.7$ dan nilai AVE dikatakan baik bila memiliki nilai $\geq 0.5$.

b. Model Struktural atau Inner Model

Pada uji kecocokan model terdapat 3 indeks pengujian yaitu: average path coefficient (APC) harus $\mathrm{p}<0.05$, average $R$ square $(\mathrm{ARS}) \mathrm{p}<0.05$ dan average varian factor (AVIF) $<3.3$.

\section{Pengujian hipotesis}

Pengujian hipotesis dilakukan dengan uji statistik $\mathrm{t}$ (t-test). Kalau dalam pengujian ini diperoleh $p$-value $<0,05$ (a $5 \%$ ), berarti pengujian signifikan, dan sebaliknya kalaup-value> 0,05 (a 5\%), berarti tidak signifikan.

\section{HASIL DAN PEMBAHASAN}

\section{Karakteristik Responden}

Karakteristik responden dalam penelitian ini terdiri dari umur responden, Pendidikan yang ditempuh, pengalaman usaha tani, status kepemilikan lahan, kepemilikan luas lahan serta pengalaman sebagai anggota kelompok tani. Dimana karaakteristik responden penelitian dapat dilihat pada Tabel 1.

Tabel 1. Karakteristik Responden

\begin{tabular}{|c|c|c|c|c|}
\hline No & Karakteristik & Kategori & Percen (\%) & Rata-rata \\
\hline 1. & Umur & $\begin{array}{l}\text { 29-36 Tahun } \\
\text { 37-44 Tahun } \\
\text { 45-57 Tahun } \\
\text { 53-60 Tahun } \\
>60 \text { Tahun }\end{array}$ & $\begin{array}{r}9.92 \\
24.43 \\
29.01 \\
16.01 \\
20.61\end{array}$ & 47 Tahun \\
\hline 2. & Pendidikan & $\begin{array}{l}\text { Tidak tamat SD } \\
\text { SD } \\
\text { SMP } \\
\text { SMA } \\
\text { D3/S1 }\end{array}$ & $\begin{array}{r}46.57 \\
36.64 \\
8.40 \\
6.87 \\
1.58\end{array}$ & \\
\hline 3. & Pengalaman Usaha Tani & $\begin{array}{l}\text { 5-11 Tahun } \\
\text { 12-18 Tahun } \\
\text { 19-25 Tahun } \\
\text { 26-32 Tahun } \\
\text { 33-40 Tahun }\end{array}$ & $\begin{array}{l}4.43 \\
1.37 \\
9.85 \\
4.43 \\
9.92\end{array}$ & 20 tahun \\
\hline 4. & Kepemilikan Lahan & $\begin{array}{l}\text { Penggarap } \\
\text { Pemilik Bukan Penggarap } \\
\text { Pemilik Penggarap }\end{array}$ & $\begin{array}{r}93.13 \\
3.82 \\
3.05\end{array}$ & \\
\hline 5. & Kepemilikan Luas Lahan & $\begin{array}{l}0.5-1 \mathrm{Ha} \\
1.1-1.6 \mathrm{Ha} \\
1.7-2.1 \mathrm{Ha} \\
2.2-2.8 \mathrm{Ha} \\
>2.8 \mathrm{Ha} \\
\end{array}$ & $\begin{array}{r}25.19 \\
23.66 \\
9.16 \\
25.95 \\
16.03 \\
\end{array}$ & $1.2 \mathrm{Ha}$ \\
\hline 6. & $\begin{array}{l}\text { Pemgalaman Sebagai } \\
\text { Anggota Kelompok Tani }\end{array}$ & $\begin{array}{l}\text { 5-11 Tahun } \\
\text { 12-17 Tahun } \\
\text { 18-23 Tahun } \\
\text { 24-29 Tahun } \\
\text { 30-35 Tahun }\end{array}$ & $\begin{array}{l}28.24 \\
16.79 \\
12.21 \\
13.74 \\
29.01\end{array}$ & 18 tahun \\
\hline
\end{tabular}

\section{Deskriptif Variabel Peneliti}

Terdapat tiga variabel dalam penelitian ini yang terdiri lagi dari beberapa indikator yang mewakili. Dimana deskriptif variabel penelitian yaitu;

\section{Lingkungan Kerja Kelompok Tani}

Rata-rata persepsi petani terhadap peranan sumberdaya kontak tani dapat dilihat pada Gambar 2.

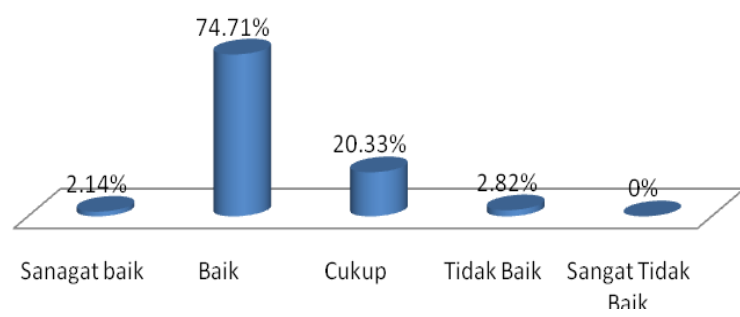

Gambar 2. Persepsi terhadap lingkungan kerja kelompok tani 
Berdasarkan Gambar 2 dapat dilihat bahwa rata-rata pendapat petani terhadap lingkungan kerja kelompok tani adalah baik dengan presentase sebesar $74.71 \%$. dimana penilaian lingkungan kerja kelompok taani terdiri dari delapan indikator yaitu Hubungan kontak tani dengan anggota kelompok tani, Pengolahan Lahan Pertanian, Sistem Pola Tanam, Perawatan dan Pemupukan Lahan dengan Pestisida, Pengelolaan Jaringan Irigasi, Perawatan Jaringan Irigasi, Penggunaan Alat Mesin Pertanian, dan Sistem Penghematan Air.

\section{Peranan sumberdaya kontak tani}

Rata-rata persepsi petani terhadap peranan sumberdaya kontak tani dapat dilihat pada Gambar 3.

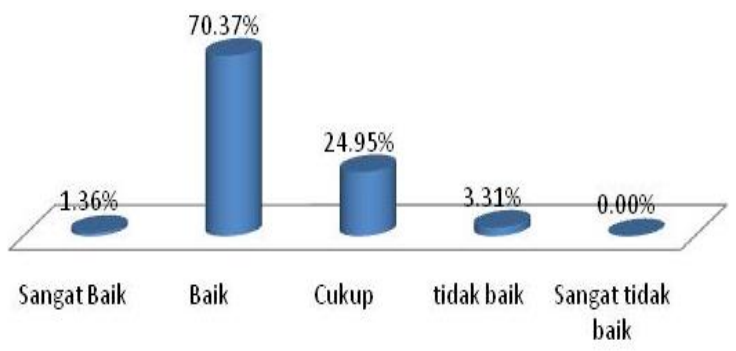

\section{Gambar 3. Persepsi terhadap peranan sumberdaya Kontak Tani}

Berdasarkan gambar diatas dapat diketahui bahwa secara Rata-rata persepsi petani terhadap peranan sumberdaya kontak tani adalah baik yaitu sebesar $70.37 \%$.

\section{Kinerja petani}

Rata-rata persepsi petani terhadap peranan sumberdaya kontak tani dapat dilihat pada Gambar 4. .

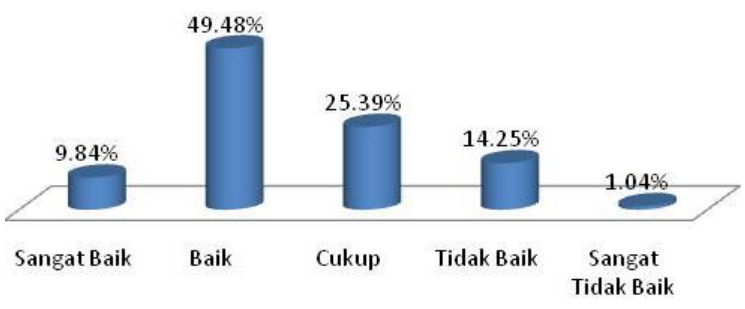

Gambar 4. Rata-rata kinerja petani
Berdasarkan Gambar 4 diatas dapat dilihat bahwa presentase rata-rata paling tinggi untuk kinerja petani adalah baik dengan tingkat presentase sebesar $49.48 \%$ dan memiliki tiga indikator yang menjelaskannya yaitu: Tingkat pendapatan anggota kelompok tani, Proaktif dan kepatuhan anggota kelompok tani, dan Kepuasan anggota kelompok tani.

\section{Analisis Structural Equation Modeling (SEM)}

a. Menilai Outer Model atau Measurement Model

Discriminan Validity

Nilai ini merupakan nilai cross loading faktor yang berguna ntuk mengetahui apakah konstruk memiliki diskriminan yang memadai yaitu dengan cara membandingkan nilai loading pada konstruk yang dituju harus lebih besar dibandingkan dengan nilai loading dengan konstruk yang lain (Tabel 2).

\section{Tabel 2. Uji Validitas berdasarkan Cross Loading konstruk en- dogen}

\begin{tabular}{lccc}
\hline Indikator & $\begin{array}{c}\text { Lingkungan kelompok tani } \\
(\mathrm{X})\end{array}$ & $\begin{array}{c}\text { Sumberdaya Kontak } \\
\text { Tani (Y1) }\end{array}$ & Kinerja Petani (Y2) \\
\hline X1 & 0.365 & -0.382 & 0.788 \\
X2 & 0.722 & -0.558 & 0.049 \\
X3 & 0.892 & 0.175 & -0.275 \\
X4 & 0.716 & 0.641 & -0.469 \\
X5 & 0.401 & 0.730 & -0.031 \\
X6 & 0.710 & -0.420 & 0.028 \\
X7 & 0.037 & -0.644 & 0.759 \\
X8 & 0.295 & -0.141 & 0.748 \\
Y1.1 & -0.319 & 0.317 & 0.768 \\
Y1.2 & -0.123 & 0.854 & -0.111 \\
Y1.3 & 0.488 & 0.715 & -0.087 \\
Y1.4 & -0.160 & 0.892 & -0.097 \\
Y2.1 & 0.490 & -0.274 & 0.392 \\
Y2.2 & -0.150 & 0.363 & 0.846 \\
Y2.3 & -0.075 & -0.321 & 0.864 \\
\hline
\end{tabular}

Tabel 2 dapat dilihat bahwa terdapat beberapa nilai loading factor untuk setiap indikator dari masing-masing variabel laten memiliki nilai loading factor yang lebih kecil dibanding nilai loading jika dihubungkan dengan variabel laten lainnya yaitu varibel $\mathrm{X} 1, \mathrm{X} 5, \mathrm{X} 7, \mathrm{X} 8, \mathrm{Y} 1.1$ dan Y2.1. Hal ini berarti bahwa beberapa variabel tidak memiliki discriminant validity yang baik dan valid. 


\section{Convergent validity}

Nilai Convergent validity adalah nilai loading factor pada variabel laten dengan indikator-indikatornya. Ukuran reflektif individual dikatakan berkorelasi jika lebih dari 0.5 dengan konstrak yang ingin diukur (Tabel 3).

\section{Tabel 3. Pengukuran Loading Factor}

\begin{tabular}{lcc}
\hline \multicolumn{1}{c}{ Indikator } & Loading Factor $\geq 0.50$ & Keterangan \\
\hline $\mathrm{K}$ & 0.593 & Valid \\
$\mathrm{X} 2$ & 0.961 & Valid \\
$\mathrm{X} 3$ & 0.865 & Valid \\
$\mathrm{X} 4$ & 0.767 & Valid \\
$\mathrm{X} 5$ & 0.527 & Valid \\
$\mathrm{X} 6$ & 0.955 & Valid \\
$\mathrm{X} 7$ & $\mathbf{0 . 1 1 4}$ & Tidak Valid \\
$\mathrm{X} 8$ & $\mathbf{0 . 4 8 8}$ & Tidak Valid \\
Y1.1 & 0.553 & Valid \\
Y1.2 & 0.862 & Valid \\
Y1.3 & 0.718 & Valid \\
Y1.4 & 0.908 & Valid \\
Y2.1 & 0.677 & Valid \\
Y2.2 & 0.776 & Valid \\
Y2.3 & 0.931 & Valid \\
\hline
\end{tabular}

Tabel 3 dapat diketahui bahwa terdapat 3 konstruk penelitian tidak memenuhi kriteria convergant validity karena memiliki nilai factor loading $\leq 0.50$ yaitu variabel $\mathrm{X} 7$ dan $\mathrm{X} 8$ dengan masingmasing nilai nilai loding faktornya adalah 0.114 dan 0.448 . Dengan demikian maka dilakukan pengeluaran indikator $\mathrm{X} 7$ dan X8 dari variabel penelitian setelah itu dilakukan pengujian kembali. Setelah pengeluaran variabel tersebut makadapat disimpulkan convergant validity dari variabel kinerja, motivasi, lingkungan kerja, karakteristik SDM dan insentif adalah valid dan tidak terdapat permasalahan konvergen validity dalam penelitian ini.

\section{Reliabilitas atau Unidimensionalitas}

Memastikan bahwa tidak ada masalah terkait pengukuran maka langkah terakhir dalam evaluasi outer model adalah menguji unidimensionalitas dari model. Pengujian konsistensi pengukuran (reliabilitas) dengan AVE dan CR. Reliabilitas tinggi menunjukkan bahwa indikatorindikator mempunyai konsistensi tinggi dalam mengukur konstruk latennya. Reliabilitas dapat diketahui melalui nilai Com- posite Reliability (CR) dan Average Variance Extracted (AVE). CR dikatakan baik bila memeiliki nilai $\geq 0.7$ dan nilai AVE dikatakan baik bila memiliki nilai $\geq 0.5$. Data hasil pengujian CR dan AVE ditunjukkan pada Tabel 4.

\section{Tabel 4. Nilai Reliability konstruk eksogen terhadap konstruk endogen}

\begin{tabular}{llll}
\hline \multicolumn{1}{c}{ Konstruk } & $\begin{array}{l}\text { Composite } \\
\text { Average Variance } \\
\text { Extract (AVE) } \geq 0.5\end{array}$ & $\begin{array}{l}\text { Realiability } \\
(\mathrm{CR}) \geq 0.7\end{array}$ & Kesimpulan \\
\hline Lingkungan Kelompok Tani & 0.514 & 0.811 & Reliabilitas Baik \\
Sumberdaya Kontak Tani & 0.534 & 0.805 & Reliabilitas Baik \\
Kinerja Petani & 0.539 & 0.762 & Reliabilitas Baik \\
\hline
\end{tabular}

Berdasarkan hasil uji validitas dan reliabilitas dari model pengukuran, dapat disimpulkan bahwa semua variabel teramati valid mengukur variabel latennya, dan realiabilitas model pengukurannyapun baik. Hal ini menunjukkan bahwa indikator reliable dalam menyusun konstruk eksogen.

\section{b. Pengujian Model Struktural (Inner Model)}

Tahap selanjutnya adalah melakukan evaluasi struktural (inner model) yang meliputu uji kecocokan model (model fit), path coefficient dan $\mathrm{R}^{2}$. Pada uji kecocokan model terdapat 3 indeks pengujian yaitu: average path coefficient (APC), average $R$-square (ARS) dan average varian factor (AVIF) lihat Gambar 5.

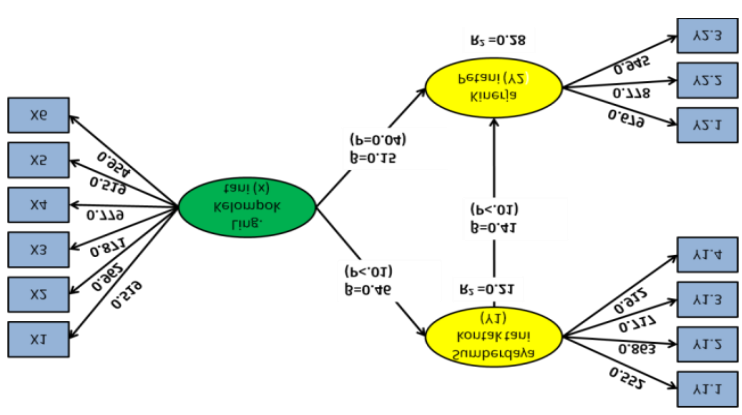

Gambar 5. Path diagram akhir 
Analisa ini dilakukan untuk memastikan bahwa model structural yang dibagun akurat. Evaluasi inner model dari beberapa indikator seperti pada Tabel 4.

Berikut ini adalah hasil output model fit indices yang disajiakn pada Tabel 5.

\section{Tabel 5. Model Fit Indices}

\begin{tabular}{lllll}
\hline & Indeks & P-Value & Kriteria & Keterangan \\
\hline APC & 0.342 & $<0.001$ & $\mathrm{p}<0.05$ & Diterima \\
ARS & 0.244 & $<0.001$ & $\mathrm{p}<0.05$ & Diterima \\
AVIF & 1.788 & $<0.001$ & AVIF $<3.3$ & Diterima \\
\hline
\end{tabular}

Berdasarkan Tabel 5 maka inner model dapat diterima, sehingga pengujian hipotesa atau interprestasi model dapat dilakukan.

\section{Analisis Model Struktural}

Semua hipotesis penelitian membuktikan adanya hubungan signifikan pada tingkat keyakinan $95 \%$ dengan $P$-value $\leq$ 0.05. Secara umum hasil Tabel 6 menandakan hubungan variabel independen terhadap variabel dependen.

Tabel 6. Kesimpulan Uji Hipotesis

\begin{tabular}{|c|c|c|c|c|}
\hline Hipotesis & Path & $\begin{array}{c}P- \\
\text { Value }\end{array}$ & Estimasi & Hasil \\
\hline \multicolumn{5}{|c|}{ Pengaruh langsung (Direceffect) } \\
\hline $\mathrm{H} 1$ & $\begin{array}{lrl}\text { Lingkungan } & \text { KelompokTani } \\
\text { Sumberdaya Kontak Tani }(\mathrm{Y} 1) & (\mathrm{X})\end{array}$ & $\leq 0.01$ & 0.46 & Diterima \\
\hline $\mathrm{H} 2$ & $\begin{array}{l}\text { Sumberdaya Kontak Tani } \quad(\mathrm{Y} 1) \rightarrow \mathrm{Y} \\
\text { Kinerja Petani }(\mathrm{Y} 2)\end{array}$ & $\leq 0.01$ & 0.41 & Diterima \\
\hline $\mathrm{H} 3$ & $\begin{array}{l}\text { Lingkungan Kelompok Tani }(\mathrm{X}) \rightarrow \text { Kinerja } \\
\text { Petani }(\mathrm{Y} 2)\end{array}$ & 0.04 & 0.15 & Diterima \\
\hline
\end{tabular}

Berikut ini adalah penjelasan analsisi secara mendalam dari masing-masing hipotesis.

Analisis hipotesis H1 terbukti diterima, karena $P$-value $\leq$ 0.01dengan (tingkat keyakinan 95\%) $\leq 0.05$ yang berarti terdapat hubungan signifikan antara variabel lingkungan kelompok tani (X) terhadap sumberdaya kontak petani (Y1). Nilai estimasi yang ditunjukkan oleh Tabel diatas yaitu 0.46 menandakan bahwa variabel lingkungan kelompok tani (X)adalah 0.46 signifikan dalam hubungannya menuju sumberdaya kontak petani (Y1) yang terasosiasi positif. Dari nilai p-value dan nilai estimasi tersebut, peneliti menganalisis terdapatnya hubungan positif yang signifikan diantara kedua variabel laten tersebut. Dapat diinterprestasikan bahwa lingkungan kelompok tani Desa Sidourip Kecamatan Argamakmur Kabupaten Bengkulu Utara memiliki hubungan yang baik dengan sumberdaya kontak petani (Y1) tersebut, yang berarti semakin baik lingkungan kelompok tani maka sumberdaya kontak tanipun akan semakin baik. Dimana berpengaruhnya lingkungan kelompok tani (X) terhadap sumberdaya kontak tani (Y1) dipengaruhi oleh variabel manifes yang mendukungnya yaitu hubungan kontak tani dengan anggota (X1), pengolahan lahan pertanian (X2), sistem pola tanam (X3), pemupukan dan perawatan lahan denga pestisida (X4), Pengelolaan jaringan irigasi(X5) dan perawatan jaringan irigasi(X6).

Selanjutnya hipotesis H2, dimana hipotesis $\mathrm{H} 4$ diterima, karena $p$-value yaitu $\leq 0.01$ dengan (tingkat keyakinan 95\%) adalah $\leq 0.05$. Penerimaan H3 berarti menunjukkan adanya hubungan yang signifikan antara variabel sumberdaya kontak tani (Y1) terhadap variabel kinerja petani (Y2). Nilai koefisien (Y1) terhadap variabel kinerja petani (Y2) terantisipasi positif menunjukkan 0.552 signifikan. Kondisi ini mendorong adanya hubungan yang signifikan dan kuat diantara kedua variabel di atas. Dapat di interprestasikan bahwa variabel sumberdaya kontak tani (Y1) mempunyai peran dalam meningkatkan kinerja petani (Y2) Di Kabupaten Seluma. Dari penjelasan yang telah dipaparkan, dapat diketahui bahwa berpengarunya sumberdaya kontak tani (Y1) terhadap kinerja petani (Y2), didukung oleh variabel manifest yang mendukungnya. Jika kinerja petani didukung oleh 3 variabel manifest maka sumberdaya kontak tani didukung oleh 4 variabel manifest yaitu, memfasilitasi anggota mencapai tujuan (Y1.1), Membantu anggotanya memenuhi kebutuhan (Y1.2), Mewujudkan nilai ke- 
lompok (Y1.3) dan mewakili pendapat anggota dalam berintegrasi dengan pihak lain (Y4).

Beberapa penelitian yaitu (Budianti dan Kartini, 2014; Nadia. dkk, 2014; Masfuruddin dan Muhammad, 2016; Sofyan, 2013; Suharyono dan Busyra, 2016; Rahmawati. dkk, 2014; Wahyuni, 2003), memberikan kesimpulan yang sama bahwa lingkungan secara signifikan akan memberikan pengaruh terhadap kinerja. Dimana Wahyuni (2003) menyebutkan bahwa kinerja klompook taniperlu dilakukannya pemberdayaan ang diawali dengan hubungan yang baik antara anggota dan kontak tani, kemudian faktorfaktor yang mempengaruhi kinerja klompok tani antara lain: Struktur dan asset kelompok, kepemilikan lahan, kredibilitas pengurus dan kelembagaan penunjang.

Analisis hipotesis $\mathbf{H 3}$ terbukti diterima, karena $P$-value $\leq 0.04$ dengan (tingkat keyakinan 95\%) $\leq 0.05$ yang berarti terdapat hubungan signifikan antara variabel lingkungan kelompok tani (X) terhadap kinerja petani (Y2). Nilai estimasi yang ditunjukkan oleh Tabel diatas yaitu 0.15 menandakan bahwa variabel lingkungan kelompok tani (X)adalah 0.15 signifikan dalam hubungannya menuju kinerja petani (Y2) yang terasosiasi positif. Dari nilai $p$-value dan nilai estimasi tersebut, peneliti menganalisis terdapatnya hubungan positif yang signifikan diantara kedua variabel laten tersebut. Dapat diinterprestasikan bahwa lingkungan kelompok tani Desa Sidourip Kecamatan Argamakmur Kabupaten Bengkulu Utara memiliki hubungan yang baik dengan kinerja petani (Y2) tersebut, yang berarti semakin baik lingkungan kelompok tani maka kinerja ptani akan semakin baik.Dari penjelasan yang telah dipaparkan, dapat diketahui bahwa berpengarunya lingkungan kelompok tani (X) terhadap kinerja petani (Y2), didukung oleh variabel manifest yang mrndukungnya. Jika Lingkungan kelompok didukung oleh 6 variabel manifest maka kinerja petani didukung oleh, pendapatan anggota kelompok (Y2.1) proaktif dan kepatuhan anggota kelompok tani (Y2.2) dan Kepuasan naggota kelompok (Y2.3)

Beberapa penelitian yang sejalan dengan hasil penelitian ini diantara lain, (Mardikanto dan Padmaningrum, 2007; Putra, 2016), yang memberikan kesimpulan bahwa sumberdaya kontak tani termasuk gaya kemimpinan yang dimiliki kontak tani secara signifikan berpengaruh positif terhadap kinerja anggota kelompok tani, selain itu gaya kepemimpinan juga akan berpengaruh terhadap difusi inovasi tegnologi yang diterima oleh para anggota kelompok tani. Kemudian menurut Irawati dan Yantu (2015), Kinerja klompok tani juga secara signifikan akan mempengaruhi pendapatan anggota kelompok tani.

\section{KESIMPULAN}

Berdasarkan hasil peelitian dan pembahasan dapat diambil simpulan sebagai berikut:

1. Lingkungan kelompok tani berpengaruh positif terhadap sumberdaya kontak tani. Variabel manifes lingkungan kelompok tani yang sangat reliabel mempengaruhi peranan sumberdaya kontak tani adalah: hubungan kontak tani dengan anggota, pengolahan lahan pertanian, sistem pola tanam, pemupukan dan perawatan lahan denga pestisida, Pengelolaan jaringan irigasi dan perawatan jaringan irigasi.

2. Lingkungan kelompok tani berpengaruh positif terhadap kinerja petani. Variabel manifes lingkungan kelompok tani yang sangat reliabel mempengaruhi peranan sumberdaya kontak tani adalah: pendapatan anggota kelompok proaktif dan kepatuhan anggota kelompok tani dan Kepuasan naggota kelompok.

3. Peranan sumberdaya kontak tani berpengaruh positif terhadap kinerja petani. Variabel manives sumberdaya 
kontak tani yang sangat reliabel mempengaruhi efektifitas kelompok tani adalah: memfasilitasi anggota mencapai tujuan, Membantu anggotanya memenuhi kebutuhan, Mewujudkan nilai kelompok dan mewakili pendapat anggota dalam berintegrasi dengan pihak lain.

\section{DAFTAR PUSTAKA}

Irawati, E., dan Yantu, M. R. 2015. Kinerja kelompok Tani Dalam Menunjang Pendapatan Usaha Tani Padi Sawah Desa Sidera Kecamatan Sigi Biromaru Kabupaten Sigi. Jurnal Agrotekbis 3 (2).

Mardikanto, T., dan Padmaningrum, D. 2007. Pengaruh Kepemimpinan Kontak Tani Terhadap Dinamika Kelompok Tani Di Kecamatan ngemplak Kabupaten Boyolali. Jurnal Agribisnis No.22.

Pertiwi, P. R., dan Heryadi, H. 2012. Peran Kepemimpinan Kontak Tani Dalam Proses Difusi Inovasi Teknologi Pengelolaan Tanaman
Dan Sumberdaya Terpadu Padi. Jurnal Matematika, sains dan Teknologi, 13 (1).

Rahmawati, N. P., dkk. 2014. Pengaruh Lingkungan Kerja Terhadap Kinerja Karyawan Jurnal Administrasi Bisnis (JAB) 8 (2).

Putra, E. A. S. 2016. Peranan Ketua Kelompok Tani dalam Mengadopsi Teknologi Budidaya Bawang Merah Di Lahan Pasir Pantai Kecamatan Saden Kabupaten Banatul. Jurnal Agro Ekonomi. 27 (2)

Sofyan, D. K. 2013. Pengaruh Lingkungan Kerja Terhadap Kinerja Pegawai. Jurnal Malikussaleh industrial Engineering 2 (1).

Suharyono dan Busyra. 2016. Kinerja Kelompok Tani Dalam Sistem Usaha Tani Padi Lahan Sub Optimal dan Metode Pemberdayaannya. 18 (1).

Wahyuni, S. 2003. Kinerja Kelompok Tani Dalam Sistem Usaha Tani Padi dan Metode Pemberdayaannya. Jurnal Litbang Pertanian 22 (1). 